\title{
IMPLEMENTASI PENDIDIKAN KARAKTER TERINTEGRASI KURIKULUM DAN METODE PEMBELAJARAN PADA MASA PANDEMI COVID-19
}

\section{THE IMPLEMENTATION OF CHARACTER EDUCATION INTEGRATED TO CURRICULUM AND LEARNING METHODS DURING COVID-19 PANDEMIC}

\author{
Galih Mustikaningrum ${ }^{1}$, Linda Pramusinta ${ }^{2}$, Sri Ayu Muhtar Umar Buamona ${ }^{3}$, \\ Edi Cahyadi $^{4}$, Wahyu Istiqomah ${ }^{5}$ \\ ${ }^{1,2,3}$ Pascasarjana Universitas Negeri Semarang, \\ ${ }^{3,4}$ SD Negeri 3 Pakis, Kradenan, Grobogan \\ ${ }^{1,2,3} \mathrm{Jl}$. Kelud Utara III, Petompon, Gajahmungkur, Semarang, \\ ${ }^{4,5}$ Butak, Pakis, Kradenan, Kabupaten Grobogan, Jawa Tengah \\ Email: monicagalih@gmail.com ${ }^{1}, \underline{\text { lindapramusinta13@gmail.com }}{ }^{2}$, \\ sriayubuamona@gmail.com $^{3}$, edicahyadi636@gmail.com ${ }^{4}$, wistiqomah3@gmail.com ${ }^{5}$
}

Submitted:24-11-2020, Revised:03-12-2020, Accepted:07-12-2020

\begin{abstract}
Abstrak
Kompetensi inti pendidikan di Indonesia salah satunya adalah membentuk karakter siswa, oleh karena itu strategi yang tepat untuk mencapai hal tersebut perlu dilakukan. Tujuan penelitian ini adalah mendeskripsikan implementasi Penguatan Pendidikan Karakter (PPK) yang terintegrasi oleh kurikulum serta model pembelajaranya dan gambaran sekolah pada penanganan wabah pandemi covid-19. Jenis penelitian ini adalah penelitian deskriptif kualitatif yang dilakukan di MI Al Islam Gunungpati pada semester ganjil tahun pelajaran 2020/2021. Subjek penelitian ini adalah kepala sekolah dan guru kelas. Data yang diperoleh dari penelitian ini dari wawancara, dokumentasi, dan observasi. Hasil dari penelitian ini didapatkan bahwa penguatan pendidikan karakter siswa yang terintegrasi kurikulum sudah baik dilakukan karena sudah memasukan nilai karakter di administrasi guru seperti silabus dan RPP. Pada PPK yang terintegrasi di model pembelajaran sudah menerapkan anjuran pemerintah yaitu menerapkan pembelajaran siswa aktif. Pada PPK di saat pandemi covid-19 orang tua siswa juga menjadi penilai pendidikan karakter anaknya karena proporsi tatap muka dengan guru kelas terbatas.
\end{abstract}

Kata Kunci: Penguatan Pendidikan Karakter, Kurikulum, Model Pembelajaran, Covid-19.

\begin{abstract}
One of the core competencies of education in Indonesia is building the students' characters so that the right strategy to achieve this needs to be done. This study aimed to describe the implementation of Strengthening Character Education or PPK, which was integrated by the curriculum, the learning model, and schools' description during Covid-19 pandemic. This study used a qualitative descriptive method, and it was conducted at MI Al Islam Gunungpati, the odd semester of the 2020/2021 school year. The subjects of this study were the principal and class teachers. The data were obtained through documentation and observation. The results indicated that the students' character education integrating into the curriculum was good because it has included character values in the syllabus and lesson plans. PPK that was integrated into the learning model had applied government recommendations to implement active student learning. To strengthen Character Education during the Covid-19 pandemic, the students' parents were also evaluators of their children's educational character because the students had limited face-to-face learning classes with teachers.
\end{abstract}

Keywords: Strengthening Character Education, Curriculum, Learning Models, Covid-19. 
How to Cite: Mustikaningrum, G., Pramusinta, L., Buamona, S. A. M. U., Cahyadi, E., \& Istiqomah, W. (2020). Implementasi Pendidikan Karakter Terintegrasi Kurikulum dan Metode Pembelajaran pada Masa Pandemi Covid-19. AULADUNA: Jurnal Pendidikan Dasar Islam, 7(2), 154-164.

\section{Pendahuluan}

Penguatan Pendidikan Karakter (PPK) merupakan suatu tujuan pendidikan di sekolah untuk meningkatkan karakter siswa melalui proses pembentukan, transformasi, transmisi, dan pengembangan potensi siswa tentang etik, spiritual, estetik, literasi, numerasi, dan kinestetik sesuai dengan dasar negara Indonesia (Muldani, Anriani, \& Fatah, 2019). Implementasi PPK di sekolah dilakukan dengan beberapa pendekatan diantaranya PPK berbasis kelas, PPK berbasis budaya sekolah, dan PPK berbasis masyarakat (Albertus, 2015). Ketiga pendekatan tersebut saling terikat dan berkesinambungan (Widyahening \& Wardhani, 2016). Penguatan karakter anak di sekolah dapat diwujudkan melalui kegiatan pembelajaran, melalui pembiasaan dalam kegiatan sehari-hari di sekolah, dan kegiatan ekstrakurikuler (Septiani Rejekiningsih, Triyanto, \& Rusnaini, 2020). Penguatan pendidikan karakter meliputi langkah-langkah pembelajaran, perangkat pengajaran, metode, dan lain-lain (Hasnadi, Sumaryanto, Ekosiswoyo, \& Prihatin, 2020). Pada PPK berbasis kelas terdapat PPK terintegrasi kurikulum dan metode pembelajaran.

Integrasi PPK dalam kurikulum mempunyai arti seorang guru mengintegrasikan nilai-nilai utama PPK pada proses kegiatan belajar mengajar di setiap mata pelajaran (Islam, 2017). Tujuan pengintegrasian tersebut supaya dapat menumbuhkan dan menguatkan pengetahuan, menanamkan kesadaran, dan siswa dapat mengimplementasikan nilai-nilai utama PPK (Ahmadi, Haris, \& Akbal, 2020). Langkah-langkah yang dapat guru terapkan pada integrasi PPK dalam kurikulum adalah (1) menganalisis serta mengindentifikasi nilai karakter yang terkandung pada mata pelajaran, (2) membuat rencana pembelajaran dengan fokus penguatan karakter saat memilh metode pembelajaran, (3) mengimplementasikan rencana pembelajaran dengan baik, (4) melakukan pembelajaran sesuai rencana secara berkesinambungan, dan (5) melakukan evaluasi untuk diperbaiki kekuranganya (Maisaro, Wiyono, \& Arifin, 2018). Oleh karena itu, PPK terintegrasi kurikulum perlu diamati, karena hal tersebut memuat perencanaan, pelaksanaan dan penilaian yang dilakukan guru.

PPK yang terintegrasi dalam kurikulum dapat dilakukan melalui kegiatan belajar mengajar menggunakan suatu metode pembelajaran yang tepat (Mariyaningsih \& Hidayati, 2018). Pemilihan metode pembelajaran harus dapat membantu guru dalam memberikan pengetahuan dan keterampilan yang dibutuhkan siswa (Haryanti, 2017). Rencana pembelajaran yang dibuat guru selain harus tepat dalam menanamkan aspek kognitif siswa, guru juga harus memasukan nilai karakter yang tepat dalam pengintegrasianya ke metode pembelajaran.

Namun pada awal tahun 2020 di Indonesia tertular wabah virus corona. Menurut Etikasari, Puspitasari, Kurniasari, \& Perdanasari (2020), Corona virus (Covid-19) merupakan penyakit dengan tingkat penularan yang sangat cepat. Dampak dari Covid19 pada pendidikan di Indonesia adalah proses kegiatan belajar ditiadakan di sekolah dan diubah ke kegiatan belajar secara dalam jaringan (daring). Selain itu, dampak lain adalah guru tidak bisa menilai langsung karakter siswa serta pembatalan ujian nasional (Rizqon, 2020). Selain itu, dalam observasi yang dilakukan oleh peneliti di MI Al Islam Gunungpati, Kota Semarang diperoleh bahwa siswa tetap masuk sekolah, walaupun siswa yang masuk ke sekolah bergantian tiap rombongan belajarnya dan di kelas hanya 
berisi $50 \%$ dari jumlah siswa tiap rombongan belajar. Selain itu, siswa hanya masuk ke sekolah setiap minggu maksimal tiga hari.

Mengingat bahwa pendidikan karakter hal utama yang ada di kurikulum 2013 yaitu pada kompetensi inti pertama dan kedua maka penelitian ini bertujuan untuk mengetahui bagaimana perencanaan guru-guru di MI Al Islam Kecamatan Gunungpati, Kota Semarang dalam membuat administrasi berupa rencana pelaksanaan pembelajaran maupun silabus di saat pandemi Covid-19. Kemudian penelitian ini untuk mengetahui bagaimana implementasi model pembelajaran yang memuat karakter serta melihat bagaimana gambaran sekolah mengenai pencegahan Covid-19 di MI Al Islam Gunungpati.

\section{Metode Penelitian}

Jenis penelitian ini menggunakan pendekatan kualitatif. Penelitian ini mendeskripsikan implementasi PPK yang terintegrasi kurikulum serta metode pembelajaranya, selain itu bagaimana menamkan karakter menjaga kebersihan siswa disaat pandemi Covid-19. Penelitian ini dilakukan di MI Al Islam Gunungpati, Kota Semarang pada tahun pelajaran 2020/2021. Subjek penelitian ini adalah warga sekolah yaitu kepala sekolah, guru kelas yang berjumlah sembilan guru kelas.

Instrumen pada penelitian ini adalah pengamatan dan wawancara. Teknik pengumpulan data pada penelitian ini menggunakan observasi melihat gambaran umum dan pengimplementasian PKK pada masa pandemi Covid-19 wawancara terstruktur kepada kepala sekolah dan guru kelas, dan dokumentasi yang dilakukan dengan cara melihat administrasi berupa RPP dan silabus untuk mengetahui karakter apa saja yang akan dilakukan oleh guru. Teknik keabsahan data pada penelitian ini mengunakan ketekunan pengamatan dan triangulasi data. Teknik analisis data menggunakan reduksi data, penyajian data, memverifikasi data, dan penyajian data untuk kesimpulan.

\section{Hasil dan Pembahasan}

\subsection{Hasil}

Hasil penelitian dan pembahasan berupa deskripsi implementasi Penguatan Pendidikan Karakter (PPK) yang terintegrasi kurikulum dan model pembelajaran yang diterapkan serta gambaran umum karakter kebersihan dimasa pandemi virus Covid-19.

Gambaran umum MI Al Islam mempunyai 6 rombongan belajar yaitu dari kelas 1 sampai kelas 6. Di MI tersebut mempunyai kepala sekolah dan 9 orang guru. Guru di MI Al Islam mempunyai ijazah minimal S-1. Oleh karena itu sumber daya manusia di MI Al Islam tergolong baik. Sehingga, untuk menerapkan aturan yang ada khususya pada peningkatan pendidikan karakter para guru sudah memahami.

Pada pengetahuan tentang penguatan pendidikan karakter melalui wawancara dengan kepala sekolah didapatkaan kutipan wawancara sebagai berikut.

\section{Peneliti : Apakah penguatan karakter perlu dilakukan?}

Kepala Sekolah : Pengembangan pendidikan karakter di MI sangat perlu dilakukan karena pendidikan karakter yang baik harus dilakukan sejak dini, apalagi namanya siswa sekolah khususnya sekolah dasar, doktrin guru itu lebih besar sejauh yang saya amati. Pendidikan karakter juga termasuk visi dan misi MI ini makanya 


\section{bukan penting lagi, tapi wajib dilakukan.}

Selain kepala sekolah pertanyaan wawancara yang sama dilakukan oleh seorang guru kelas dan diperoleh jawaban PPK harus dilaksanakan, karena anak-anak sedang dalam masa degradasi dan juga karena keadaan sekarang sedang pandemi virus corona. Namun, sebagai guru harus selalu mengingatkan tentang menjadi pribadi yang baik, apalagi masih anak sekolah dasar. Karena di masa itu, doktrin guru itu lebih besar dari pada orang tua, sehingga penguatan pendidikan karakter sangat penting dilakukan.

Pada hasil PPK terintegrasi kurikulum yang dihasilkan dalam penelitian ini merupakan sebuah perencanaan penguatan karakter yang tertuang dalam silabus dan rencana pelaksanaan pembelajaran yang dibuat oleh guru di MI Al Islam Gunungpati. Biasanya guru di MI tersebut membuat perangkat pembelajaran khususnya RPP dan silabus sebelum dimulainya tahun ajaran baru, hal itu kemudian dijadikan dan dibuat dalam buku kurikulum tingkat satuan pendidikan di MI Al Islam Gunungpati. Selanjutnya tabel 1 berikut adalah hasil rekapitulasi RPP dan silabus yang memuat penguatan pendidikan karakter yang dibuat oleh 9 guru di MI Al Islam Gunungpati.

Tabel 1. Nilai Karakter yang Termuat dalam Perencanaan Pembelajaran

\begin{tabular}{|c|c|c|}
\hline Nilai Karakter & Guru yang Merencanakan & Persentase (\%) \\
\hline Kejujuran & 9 & 100 \\
\hline Kecerdasan & 9 & 100 \\
\hline Ketangguhan & 9 & 100 \\
\hline Kepedulian & 9 & 100 \\
\hline Kedisiplinan & 9 & 100 \\
\hline Tanggung jawab & 9 & 100 \\
\hline Cerdas & 9 & 100 \\
\hline Cermat & 9 & 100 \\
\hline Teliti & 9 & 100 \\
\hline Penuh penghayatan & 4 & 45 \\
\hline Kritis & 4 & 45 \\
\hline Analitis & 1 & 12 \\
\hline Santun & 9 & 100 \\
\hline Religius & 9 & 100 \\
\hline Rasa ingin tahu & 9 & 100 \\
\hline Kreatif & 9 & 100 \\
\hline Mandiri & 9 & 100 \\
\hline Kerjasama & 9 & 100 \\
\hline Kerja Keras & 9 & 100 \\
\hline Toleransi & 9 & 100 \\
\hline Gemar Membaca & 9 & 100 \\
\hline Percaya diri & 9 & 100 \\
\hline Demokratis & 9 & 100 \\
\hline Berani & 9 & 100 \\
\hline
\end{tabular}

Salah satu nilai karakter yang masih belum guru terapkan adalah analitis. Berikut adalah salah satu kutipan wawancara dengan seorang guru yang tidak menuliskan analitis sebagai tujuan. 


$\begin{array}{ll}\text { Peneliti } & \text { Mengapa ibu tidak menyertakan analitis di RPP atau } \\ \text { Guru } & \text { silabus yang dibuat? } \\ & \text { Analitis itu susah, soalnya yang kita ajar itu anak MI } \\ & \text { yang notabene untuk berpikir kritis saja sudah berat } \\ & \text { apalagi analitis, kita hanya mencoba yang bisa } \\ & \text { digapai saja mbak. }\end{array}$

Pada hasil pengamatan dokumen administrasi dan wawancara didapatkan bahwa di MI Al Islam sudah baik dalam mengintegrasikan karakter ke dalam perencanaanya. Pada hasil PPK melalui metode pembelajaran yang diambil datanya dari RPP dan silabus, diketahui bahwa semua guru atau 9 guru di MI Al Islam Gunungpati sudah menerapkan metode pembelajaran di kelas sesuai dengan anjuran kurikulum 2013. Seperti penggunaan discovery learning, problem based learning, Inkuiri, dan lainya. Penggunaan metode pembelajaran yang sesuai dengan kurikulum 2013 menurut guru kelas 5 sangat penting dalam meningkatkan karakter. Menurutnya, penggunaan metode pembelajaran seperti discovery learning membuat siswa dapat berkolaborasi dengan temannya untuk meraih sesuatu. Siswa dapat berani memaparkan hasil yang dikerjakan. Selain itu, siswa dapat menjadi seorang pemimpin walaupun hanya skala berkelompok kecil. Hal tersebut menjadikan tanggung jawab siswa menjadi besar.

Namun menurut guru kelas 5, saat masa virus corona hanya bisa memberikan materi ajar baik melalui video dan penugasan untuk dilakukan di rumah apalagi materi yang harus dipangkas. Sehingga belum maksimal untuk melakukan model pembelajaran tersebut. Guru kelas 5 tersebut juga berharap jika semester genap atau di tahun 2021 sekolah dapat masuk kembali sehingga dapat mengimplementasikan apa yang sudah dirancang.

Dari hasil temuan di RPP, silabus, dan wawancara, para guru di MI Al Islam Gunungpati hendak menerapkan metode pembelajaran yang diterapkan sesuai dengan anjuran metode pembelajaran di kurikulum 2013. Namun, keterbatasan pertemuan dengan siswa hal tersebut belum terwujud. Pertemuan yang terbatas dilakukan untuk mengumpulkan tugas yang diberikan oleh guru dan juga pertemuan tersebut hanya berlangsung kurang dari 2 jam, sehingga di kelas tidak dapat melaksanakan model pembelajaran yang direncanakan. Akibatnya, guru belum dapat menjelaskan tentang penilaian karakter siswa yang terbentuk pada masa pandemi ini, karena pembelajaran daring dan tatap muka yang terbatas masih berfokus pada pembentukan kognitif siswa. Oleh karena itu, pada perencanaan model pembelajaran yang diterapkan di MI Al Islam sudah baik dalam menerapkan model pembelajaran karena mengacu pada kurikulum 2013 yang diterapkan. Namun, pada pelaksanaanya kurang berjalan sesuai rencana sehingga penilaian tentang karakter belum terlihat.

Selanjutnya pada penanaman karakter kebersihan saat masa pandemi virus corona yang dilakukan melalui observasi dan wawancara, MI Al Islam gunungpati membuat spanduk di depan gerbang sekolah dengan tulisan "Jangan lupa jaga $3 \mathrm{M}$ (memakai masker, mencuci tangan menggunakan sabun, dan menjaga jarak). Kemudian ada keran air dekat dengan pintu gerbang sekolah dan di depan tiap kelas, walapun hanya keran air darurat seperti yang terlihat pada gambar 1 berikut. 


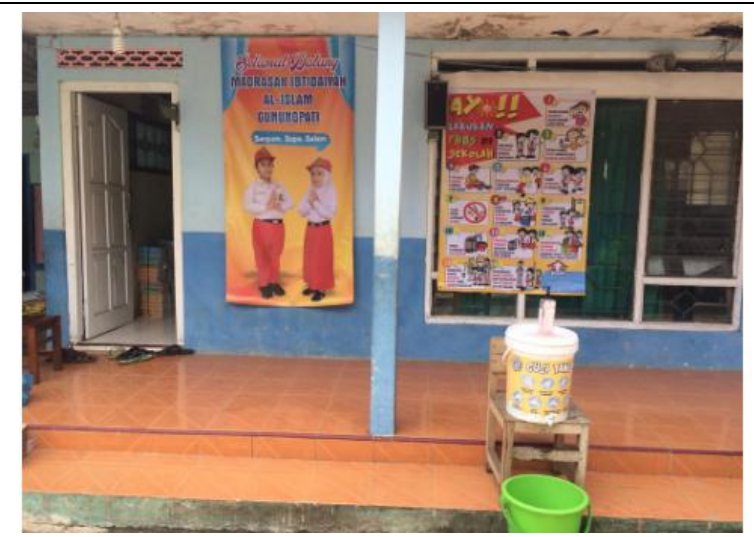

Gambar 1. Kondisi Keran Cuci Tangan di Depan Kelas

Pada proses siswa masuk ke area sekolah, siswa selalu di cek suhu tubuhnya dan juga siswa disuruh mencuci tangan menggunakan sabun yang tersedia. Selain itu, siswa yang tidak menggunakan masker akan disuruh mengambil masker terlebih dahulu jika rumahnya dekat. Di kelas terdapat tempat duduk siswa dibuat dengan cara berjauhan atau dengan jarak kurang lebih satu meter dan siswa harus selalu memakai masker.

Di dalam kelas, proses kegiatan belajar mengajar dilakukan hanya sekitar 70 menit. Proses kegiatan belajar tersebut hanya pengumpulan tugas, pemberian tugas, dan pemberian materi sedikit. Namun pada proses tersebut guru kelas selalu memerintahkan untuk selalu menjaga kesehatan dengan cara 3M. Pada hasil wawancara yang diperoleh dengan pertanyaan "Mengapa pembelajaran hanya dilakukan seperti itu", seorang guru menjawab karena mematuhi protokol kesehatan yang diterapkan yaitu tidak boleh berkumpul lama, dan tatap muka dilakukan walaupun tidak setiap hari karena siswa tingkat dasar perlu interaksi juga kepada guru dan juga supaya guru mengetahui perkembangan siswa, baik karakter maupun pengetahuannya.

Dari hal tersebut, MI Al Islam sudah baik dalam memberikan pendidikan karakter tentang kesehatan karena selalu mengajak siswa untuk menerapkan 3M dengan cara mempraktikan langsung di sekolah.

\subsection{Pembahasan}

Hasil penelitian tentang konsep dasar pendidikan karakter di MI Al Islam Gunungpati didapatkan bahwa semua sudah mengetahui tujuan dari PPK. Hal tersebut wajib dimiliki seorang pengajar. Pada dasarnya, pendidikan karakter tidak terlepas dari ilmu yang didapatkan yaitu psikologi pendidikan. Kuatnya konsep dasar penguatan pendidikan karakter yang dimiliki pengajar di MI Al Islam Gunungpati membuat penguatan karakter di sekolah tersebut menjadi lebih terarah dengan program-program yang dilakukan di sekolah. Terlebih di MI Al Islam, sumber daya manusianya sudah baik yaitu guru kelasnya minimal mempunyai ijazah S-1. Oleh karena itu dalam membuat administrasi guru bisa memahami apa yang harus diberikan kepada siswa

Pada PPK berbasis kelas terdapat PPK yang terintegrasi kurikulum. Hal tersebut lebih banyak perencanaannya dalam melakukan pembelajaran khususnya yang terkait dengan penguatan karakter. Hal tersebut dilakukan dengan membuat silabus dan RPP. Pada hasil yang menunjukan perencanaan rata-rata sangat baik karena sebanyak $92 \%$ guru di MI AL Islam memuat pendidikan karakter. Yulian, Hawanti, \& Wijayanti (2018) dan Rissanen, Kuusisto, Hanhimäki, \& Tirri (2018) menyatakan bahwa perencanaan yang baik berbanding lurus dengan hal yang baik. Kesuksesan penguatan pendidikan karakter yang diimplementasikan oleh guru terhadap siswa dilihat dari 
perubahan sikap siswa, mulai dari siswa dengan perilaku tidak baik menuju perilaku yang baik.

Pendidikan karakter wajib ditanamkan sejak dini, hal tersebut diungkapkan oleh Asmani (2011) bahwa sekolah yang menerapkan pendidikan karakter dapat mempengaruhi dalam bidang kognitif siswa. Hal ini berarti, dengan PPK yang baik mengakibatkan siswa dalam meraih prestasi, sehingga siswa mempunyai motivasi belajar dengan rajin. Pendidikan karakter ditanamkan oleh guru kepada siswa akan membuat siswa memiliki karakter yang baik, diantara perencanaan dalam silabus dan RPP karakter yang hendak diterapkan adalah karakter religius, jujur, disiplin, peduli, berpikir kritis, kerjasama, santun, percaya diri, kreatif, dan bertanggungjawab. Karakter inilah yang membuat prestasi belajar siswa meningkat (Akbar, Samawi, Arafiq, \& Hidayah, 2014; Choudhury \& Barooah, 2016; Musyarofah, Hindarto, \& Mosik, 2013; Utami \& Mustadi, 2017; Wagner \& Ruch, 2015). Selain itu, menurut Noer, Tambak, \& Sarumpaet (2017), pemahaman pendidikan karakter melalui behavior di lingkungan sekolah baik kondisi maupun kegiatannya. Sehingga, guru tidak hanya menjadi pengajar namun dapat menjadi teladan untuk siswa.

PPK melalui metode pembelajaran di MI Al Islam Gunungpati dilakukan dengan metode pembelajaran yang bermacam-macam. Metode pembelajaran utama menggunakan anjuran dari pemerintah seperti discovery learning, PBL, dan inkuiri. Namun terkadang guru masih menggunakan metode ekspositori seperti pelajaran matematika karena pelajaran matematika jika hanya dibahas oleh sesama siswa, mereka akan menjadi kesulitan. Selain itu, metode pembelajaran yang digunakan seperti pembelajaraan kooperatif dengan berbagai macam tipe. Pembelajaran kooperatif dilakukan untuk menumbuhkan karakter kerjasama, tanggung jawab, dan dapat membuat siswa berlomba karena dalam pembelajaran kooperatif pengajar terkadang memberikan hadiah untuk kelompok terbaik. Pembelajaran kooperatif yang meningkatkan karakter (Ariawan, 2018; Pasani, Kusumawati, \& Imanisa, 2018; Rahayu, 2016).

Pada perencanaan pembelajaran pengajar selalu memberikan LKS, buku paket, dan memberikan model pembelajaran yang berbeda-beda. Terkadang pembelajaran dilakukan di dalam kelas dan ada pula yang diluar kelas. Pemberian LKS atau buku paket diharapkan siswa dapat belajar sendiri agar dapat menumbuhkan karakter mandiri. Pada pelaksanaan pembelajaran pengajar dapat mengarahkan siswa untuk berpikir kritis, melakukan pembelajaran berkelompok, serta terbentuknya komunikasi yang baik antara siswa dengan guru. Hal tersebut dapat terjadi karena siswa SD masih terdoktrin dengan kuat oleh perkataan guru. Pada umumnya, siswa SD lebih mendengarkan perkataan guru dari pada orang tuanya (Rahmat, Sepriadi, \& Daliana, 2017). Seorang pengajar harus selalu memberikan karakter supaya siswa menjadi lebih baik dalam kepribadianya. Kemudian, pada penilaian dalam proses kegiatan belajar secara daring, guru hanya dapat melihat nilai kedisiplinan siswa. Hal tersebut terjadi karena dalam pengumpulan tugas dilihat dari jam pengumpulan hasil pekerjaan siswa.

Pada pemanfaatan teknologi, pengajar di MI Al Islam Gunungpati biasa dalam memanfaatkan laptop dan LCD untuk menonton film yang berisi karakter baik karakter kebersamaan serta daya juang yang tinggi. Penggunaan film dalam penguatan karakter sangat penting untuk siswa (Arumsari \& Anggarasari, 2019; Bisaha, 2019; Nugrahani, 2017). Hal tersebut karena siswa juga dapat rileks karena pembelajaran tidak hanya interaksi guru dengan siswa. Selain itu, pengajar juga selalu menyuruh siswanya untuk 
pergi keperpustakaan supaya siswa dapat menambah wawasan dan menemukan sesuatu yang sekiranya Ia sukai.

Di saat masa pandemi Covid-19, pembelajaran hanya dilakukan melalui pemberian tugas siswa disuruh membuka link yang diberikan kepada guru kemudian menceritakan apa yang terkandung dalam link tersebut. Kemudian, pendidikan karakter juga diterapkan dalam pembelajaran daring. Contoh penerapan tersebut bersifat persuasif yaitu selalu menjaga kesehatan supaya tidak terpapar virus corona. Pandemi ini menjadi hambatan yang sangat berat karena keterbatasan pertemuan dalam pembelajaran yang membuat guru menjadi lebih sukar untuk mengamati karakter siswa.

Pada gambaran obyek MI Al Islam terdapat spanduk tentang melawan virus corona. Hal tersebut sebagai upaya sekolah yang mendukung program pemerintah serta menjaga warga sekolah dari paparan virus corona. Selalu mencuci tangan menggunakan sabun, memakai masker, dan menjaga jarak diharapkan selalu menjadi kebiasaan siswa dalam kehidupan sehari-hari, baik di lingkungan sekolah ataupun masyarakat. Hal tersebut menjadi tindakan preventif yang bisa sekolah lakukan untuk kesehatan siswa. Tindakan tersebut merupakan salah satu upaya memutus sebaran virus corona (Karo, 2020).

Implikasi dari penjelasan di atas, untuk memutus penyebaran Covid-19 di dunia pendidikan khususnya pada implementasi PPK terintegrasi kurikulum dan metode belajar dengan keterbatasan tatap muka oleh guru dan siswa. Guru dapat membuat administrasi seperti silabus dan RPP yang dapat melihat karakter siswa secara tepat pada proses belajar secara daring. Walapun belum terbiasa melakukan penilaian karakter siswa jika tidak bertemu langsung, guru dapat berkomunikasi dengan orang tua tentang kondisi siswa saat belajar di rumah serta perubahan perilaku seperti apa yang biasa siswa lakukan. Namun hal tersebut juga harus didukung orang tua dengan memberikan jawaban yang jujur mengenai keadaan karakter anaknya. Hal ini dikarenakan peran tersebut dirasa lebih berpengaruh dalam menumbuhkan karakter siswa (Purnomo, 2014).

\section{Simpulan}

Implementasi penguatan pendidikan karakter di MI Al Islam Gunungpati Kota Semarang pada PPK terintergrasi oleh kurikulum yaitu sudah banyak guru yang memasukan nilai karakter dalam silabus maupun RPP yaitu karakter kejujuran, kecerdasan, ketangguhan, kepedulian, kedisiplinan, tanggung jawab, cerdas, cermat, teliti, penuh penghayatan, kritis, analitis, santun, religius, rasa ingin tahu, kreatif, mandiri, kerjasama, kerja keras, toleransi, gemar membaca, percaya diri, demokratis, dan berani. Pada integrasi dengan model pembelajaran juga sudah termuat anjuran dari kurikulum 2013 dengan menerapkan pembelajaran siswa aktif. Di saat pandemi Covid19, hambatan implementasi adalah karakter siswa tidak bisa dilihat secara langsung karena keterbatasan dalam pembelajaran tatap muka sehingga hanya dapat menilai beberapa karakter seperti kedisiplinan dengan cara melihat ketepatan waktu siswa dalam mengirim tugas. Cara melakukan penilaian karakter guru berkomunikasi melalui telepon seluler dengan orang tua dalam untuk mengetahui karakter siswa pada masa pandemi Covid-19. Selain itu, siswa MI Al Islam sudah menjalankan protokol kesehatan dengan baik. 


\section{Daftar Pustaka}

Ahmadi, M. Z., Haris, H., \& Akbal, M. (2020). Implementasi Program Penguatan Pendidikan Karakter di Sekolah. Phinisi Integration Review, 3(2), 305-315. https://doi.org/10.26858/pir.v3i2.14971

Aji, R. H. S. (2020). Dampak Covid-19 pada Pendidikan di Indonesia: Sekolah, Keterampilan, dan Proses Pembelajaran. SALAM: Jurnal Sosial \& Budaya SyarI, 7(5), 395-402. https://doi.org/10.15408/sjsbs.v7i5.15314

Akbar, S., Samawi, A., Arafiq, M., \& Hidayah, L. (2014). Model Pendidikan Karakter yang Baik (Studi Lintas Situs Bests Practices) Pendidikan Karakter di SD. Sekolah Dasar: Kajian Teori dan Praktik Pendidikan, 23(2), 139-151. http://journal.um.ac.id/index.php/jurnal-sekolah-dasar/article/view/6778

Albertus, D. K. (2015). Pendidikan Karakter di Zaman Keblinger. Gresindo.

Ariawan, S. (2018). The Effectiveness of Cooperative Learning Method (Student Team Achievement Divisions) in Christian Education. IJECA: Journal of Education and Curriculum Application, 1(3), 45-50. https://doi.org/10.31764/ijeca.v1i3.2128

Arumsari, C., \& Anggarasari, N. H. (2019). Antusias Siswa dalam Bimbingan Kelompok di Sekolah terhadap Mengembangkan Kekuatan Karakter Kesederhanaan (Temperance) dan Implikasinya pada Bimbingan dan Konseling. Journal of Innovative Counseling: Theory, Practice \& Research, 3(1), 24-29. https://journal.umtas.ac.id/index.php/innovative_counseling/article/view/388

Asmani, J. M. (2011). Buku Panduan Internalisasi Pendidikan Karakter di Sekolah. Diva Press.

Bisaha, D. (2019). Building Character: The Art and Science of Casting by Amy Cook. Theatre Topics, 29(2), 177-178. https://doi.org/10.1353/tt.2019.0026

Choudhury, S. A., \& Barooah, I. P. (2016). Character Strengths and Academic Achievement in Undergraduate College Students. Indian Journal of Positive Psychology, 7(1). $\quad$ https://www.questia.com/library/journal/1P34055684081/character-strengths-and-academic-achievement-in-undergraduate

Etikasari, B., Puspitasari, T. D., Kurniasari, A. A., \& Perdanasari, L. (2020). Sistem Informasi Deteksi Dini Covid-19. Jurnal Teknik Elektro dan Komputer, 9(2), 101-108. https://doi.org/10.35793/jtek.9.2.2020.28278

Haryanti, Y. D. (2017). Model Problem Based Learning Membangun Kemampuan Berpikir Kritis Siswa Sekolah Dasar. Jurnal Cakrawala Pendas, 3(2), 57-63. https://doi.org/10.31949/jcp.v3i2.596

Hasnadi, Sumaryanto, T., Ekosiswoyo, R., \& Prihatin, T. (2020). Strengthening the Class-Based Character Education (Case Study of SMP Negeri 6 and SMP Negeri 8 Kota Banda Aceh). Global Conferences Series: Social Sciences, Education and Humanities (GCSSSEH), 5, 83-87. https://doi.org/10.32698/GCS-PSSHERS350

Islam, S. (2017). Karakteristik Pendidikan Karakter: Menjawab Tantangan Multidimensional melalui Implementasi Kurikulum 2013. EDURELIGIA: Jurnal Pendidikan Agama Islam, 1(1), 89-101. https://doi.org/10.33650/edureligia.v1i2.50

Karo, M. B. (2020). Perilaku Hidup Bersih dan Sehat (PHBS) Strategi Pencegahan Penyebaran Virus Covid-19. Prosiding Seminar Nasional Hardiknas, 1-4. http://proceedings.ideaspublishing.co.id/index.php/hardiknas/article/view/1

Maisaro, A., Wiyono, B. B., \& Arifin, I. (2018). Manajemen Program Penguatan 
Pendidikan Karakter di Sekolah Dasar. JAMP: Jurnal Administrasi dan Manajemen Pendidikan, 1(3), 302-313.

Mariyaningsih, N., \& Hidayati, M. (2018). Bukan Kelas Biasa: Teori dan Praktik Berbagai Model dan Metode Pembelajaran Menerapkan Inovasi Pembelajaran di Kelas-Kelas Inspiratif. CV Kekata Group.

Muldani, E., Anriani, N., \& Fatah, A. (2019). Pengembangan Bahan Ajar Berorientasi Penguatan Pendidikan Karakter dalam Pembelajaran Matematika SMA pada Materi Barisan dan Deret. Journal of Authentic Research on Mathematics Education (JARME), 1(2), 124-130. http://jurnal.unsil.ac.id/index.php/jarme/article/view/784

Musyarofah, Hindarto, N., \& Mosik. (2013). Pendidikan Karakter Terintegrasi dalam Pembelajaran IPA Guna Menumbuhkan Kebiasaan Bersikap Ilmiah. UPEJ Unnes Physics Education Journal, 2(2), 41-48. https://doi.org/10.15294/upej.v2i2.2665

Noer, A., Tambak, S., \& Sarumpaet, A. (2017). Konsep Adab Peserta Didik dalam Pembelajaran Menurut Az-Zarnuji dan Implikasinya terhadap Pendidikan Karakter di Indonesia. Al-Hikmah: Jurnal Agama dan Ilmu Pengetahuan, 14(2), 181-208. https://doi.org/10.25299/al-hikmah:jaip.2017.vol14(2).1028

Nugrahani, F. (2017). The Development of Film-Based Literary Materials Which Support Character Education. Cakrawala Pendidikan, 36(3), 472-486. https://doi.org/10.21831/cp.v36i3.14219

Pasani, C. F., Kusumawati, E., \& Imanisa, D. (2018). Penerapan Model Pembelajaran Kooperatif Tipe Scramble dalam Pembelajaran Matematika untuk Membina Karakter Tanggung Jawab dan Disiplin Siswa. EDU-MAT: Jurnal Pendidikan Matematika, 6(2), 178-188. https://doi.org/10.20527/edumat.v6i2.5682

Purnomo, S. (2014). Pendidikan Karakter di Indonesia Antara Asa dan Realita. Jurnal Kependidikan, 1(1), 67-68. https://doi.org/10.24090/jk.v2i2.553

Rahayu, R. (2016). Peningkatan Karakter Tanggung Jawab Siswa SD melalui Penilaian Produk pada Pembelajaran Mind Mapping. Jurnal Konseling Gusjigang, 2(1). https://doi.org/10.24176/jkg.v2i1.562

Rahmat, N., Sepriadi, S., \& Daliana, R. (2017). Pembentukan Karakter Disiplin Siswa melalui Guru Kelas di SD Negeri 3 Rejosari Kabupaten Oku Timur. JMKSP (Jurnal Manajemen, Kepemimpinan, Dan Supervisi Pendidikan), 2(2), 229-244.

Rissanen, I., Kuusisto, E., Hanhimäki, E., \& Tirri, K. (2018). The Implications of Teachers' Implicit Theories for Moral Education: A Case Study from Finland. Journal of Moral Education, 47(1), 63-77. https://doi.org/10.1080/03057240.2017.1374244

Septiani, A. N. S. I., Rejekiningsih, T., Triyanto, \& Rusnaini. (2020). Development of Interactive Multimedia Learning Courseware to Strengthen Students' Character. European Journal of Educational Research, 9(3), 1267-1279. https://doi.org/10.12973/eu-jer.9.3.1267

Utami, K. N., \& Mustadi, A. (2017). Pengembangan Perangkat Pembelajaran Tematik dalam Peningkatan Karakter, Motivasi, dan Prestasi Belajar Siswa Sekolah Dasar. Jurnal Pendidikan Karakter, 7(1), 14-25. https://doi.org/10.21831/jpk.v7i1.15492

Wagner, L., \& Ruch, W. (2015). Good Character at School: Positive Classroom Behavior Mediates the Link Between Character Strengths and School Achievement. Frontiers in Psychology. 
https://doi.org/10.3389/fpsyg.2015.00610

Widyahening, S., \& Wardhani, M. (2016). Literary Works and Character Rducation.

International Journal of Language and Literature, 4(1), 176-180. https://doi.org/10.15640/ij1l.v4n1a20

Yuliana, D. R. R., Hawanti, S., \& Wijayanti, O. (2018). Pelaksanaan Program Penguatan Pendidikan Karakter (PPK) Berbasis Kelas melalui Manajemen Kelas di Sekolah Dasar. Jurnal Tematik, 9(2), 109-114. https://doi.org/10.24114/jt.v9i2.14434 